Pekerja Seks Komersial

\title{
PEKERJA SEKS KOMERSIAL (PSK) \\ DI WILAYAH PRAMBANAN, KABUPATEN KLATEN, JAWA TENGAH
}

Siti Munawaroh ${ }^{1}$

\begin{abstract}
Abstrak
Penelitian mengenai PSK ini bertujuan untuk mendeskripsikan faktorfaktor yang melatarbelakangi seseorang menjadi PSK. Selain itu juga bertujuan untuk mengetahui bagaimana persepsi atau pandangan masyarakat mengenai adanya PSK tersebut dan dampak yang ditimbulkannya sekaligus upaya apa yang telah dilakukan untuk memberantas PSK ini.

Penelitian ini menggunakan metode deskriptif kualitatif. Objek penelitian yaitu para PSK dan masyarakat sekitar. Sampel yang digunakan adalah purposive sampling yaitu pengambilan sampel berdasarkan pada tujuan dan pertimbangan tertentu. Teknik pengumpulan data menggunakan teknik wawancara kepada informan yang dilakukan dengan observasi non partisipan dimana hanya mengamati dan melakukan observasi serta dokumentasi. Sumber data lain yang digunakan adalah dengan menggunakan teknik triangulasi. Sedangkan untuk menganalisis data digunakan model analisis interaktif dari Miles dan Huberman yaitu pengumpulan data, reduksi data, penyajian data dan penarikan kesimpulan.

Hasil penelitian yang penulis temukan di lapangan bahwa faktor dominan yang menyebabkan seseorang bekerja menjadi PSK adalah faktor ekonomi. Faktor ekonomi dalam hal ini adalah sulit memenuhi kebutuhan sehari-hari dikarenakan tidak adanya pekerjaan yang menghasilkan uang yang cukup untuk memenuhi kebutuhan sehari-hari. Selain faktor ekonomi, ada juga faktor lainnya seperti sulitnya mencari pekerjaan, rendahnya tingkat pendidikan, faktor penghasilan menjadi PSK yang lebih mencukupi untuk memenuhi kebutuhan serta faktor keluarga. Adanya PSK juga menimbulkan pandangan negatif dari masyarakat sekitar meskipun hanya dijadikan sebagai unek-unek tanpa adanya tindakan yang nyata. Dampak yang ditimbulkan dari adanya PSK ini tidak membawa dampak yang sangat serius di dalam masyarakat. Hal ini dikarenakan baik para PSK maupun pengguna jasa bukanlah warga dari masyarakat sekitar. Tidak adanya tindakan yang nyata oleh masyarakat setempat membuat PSK-PSK di wilayah ini bisa bebas menjajakkan dirinya hingga saat ini. Upaya aparat kepolisianpun belum maksimal dalam melakukan razia ke tempat-tempat mangkal PSK khususnya ke lokasi yang dijadikan tempat penelitian.
\end{abstract}

Key Word: Pekerja Seks Komersial

${ }^{1}$ Alumni Pendidikan Sosiologi FISE UNY

DIMENSIA, Volume 4, No. 2, September 2010 | 69 


\section{A. Pendahuluan}

Dalam kehidupan sekarang ini, keberadaan wanita tuna susila atau sering disebut PSK merupakan fenomena yang tidak asing lagi dalam kehidupan masyarakat Indonesia. Namun, keberadaannya masih menimbulkan pro dan kontra di dalamnya. Beragam pandangan orang terhadap kehidupan pelacuran mengental dalam dimensinya masing-masing. Pelacur atau yang biasa disebut dengan pekerja seks komersial (PSK) dapat diartikan sebagai suatu pekerjaan yang bersifat menyerahkan diri kepada umum untuk melakukan perbuatan-perbuatan seksual dengan mendapat upah atau bayaran. Pelacuran menjadi hal yang sangat problematik. Dari sisi agama, pelacuran merupakan kemungkaran dan perbuatan dosa, namun disisi lain pelacuran merupakan kenyataan yang sulit diberantas bahkan kian mewabah dengan segala hal yang melatarbelakanginya.

Membicarakan masalah PSK juga salah satu membicarakan penyimpangan yang terjadi. PSK itu sendiri mengandung makna suatu perbuatan yang dilakukan oleh wanita dengan menawarkan serta menjual seks kepada kaum lelaki untuk melakukan hubungan seksual yang mana akan memperoleh sejumlah bayaran sebagai imbalan pemenuhan kepuasan biologis yang telah diberikan.

Banyak kekhawatiran yang timbul akibat adanya PSK ini, sebab tidak hanya membuat keresahan di tengah-tengah masyarakat, maupun penyebab degradasi moral, melainkan juga kekhawatiran akan semakin menjalarnya penyakit akibat hubungan seks yang menyimpang. Dunia kesehatan menunjukkan adanya penyakit HIV/AIDS yang merupakan salah satu penyebab adanya pelacuran di tengah masyarakat. Selain itu, adanya PSK ini akan menjadi masalah yang semakin besar apabila hal tersebut berkembang menjadi suatu profesi, terutama jika kemudian tertanam anggapan pekerjaan itu lebih mudah dilakukan dan tidak memerlukan ketrampilan khusus. Wilayah

Prambanan merupakan salah satu tempat mangkalnya para PSK sejak bertahun-tahun yang lalu. Desa Kebondalem Kidul adalah salah satu desa yang wilayahnya di gunakan sebagai tempat mangkal PSK. Hal ini sangat menarik untuk dapat diteliti tentang kehidupan para PSK yang mana mereka yang mangkal di wilayah ini adalah PSK liar. Selain itu mereka sering mangkal tidak hanya malam hari namun juga ada PSK yang mangkal di waktu siang hari.

Kehidupan wanita pekerja seks yang mangkal di wilayah tersebut bisa terjadi karena dua faktor yaitu faktor internal dan eksternal. Faktor internal adalah yang datang dari individu itu sendiri seperti yang berkaitan dengan hasrat, rasa frustasi, kualitas konsep diri dan sebagainya. Sedangkan faktor eksternal adalah sebab yang datang bukan secara langsung dari individu itu sendiri melainkan karena ada faktor luar yang mempengaruhinya untuk 
melakukan hal yang demikian seperti desakan kondisi ekonomi, pengaruh lingkungan, kegagalan kehidupan keluarga, kegagalan percintaan dan sebagainya.

Adapun tujuan yang ingin dicapai dalam penelitian ini adalah: a) untuk mengetahui faktor-faktor yang melatarbelakangi PSK memilih pekerjaan tersebut sebagai profesinya di wilayah Prambanan, Kabupaten Klaten, Jawa Tengah, b) untuk mengetahui pandangan masyarakat mengenai kasus PSK yang mangkal di wilayah Prambanan, Kabupaten Klaten, Jawa Tengah.

\section{B. Tinjauan Pustaka}

1. Tinjauan Pekerja Seks Komersial (PSK)

Suatu pelacuran adalah perilaku seks bebas yang dilakukan secara tidak sah menurut hukum dan agama yang terjadi di dalam masyarakat. Pelacuran juga merupakan suatu perilaku menyimpang dengan tujuan komersial, yang mana perilaku ini melanggar norma, kaidah dan nilainilai sosial yang berlaku dalam masyarakat, yang melakukan tidak saja akan mendapat sanksi kode etik dan nilai dari masyarakat melainkan pula sanksi agama dan hukum.

Pelacuran saat ini lebih dikenal dengan sebutan lokalisasi pekerja seks komersial (PSK) atau prostitusi. Menurut Kartini Kartono, prostitusi adalah bentuk penyimpangan seksual dengan pola-pola impuls/dorongan seks yang tidak wajar dan tidak terintegrasi dalam bentuk orang (promiskuitas) disertai eksploitasi dan komersialisasi seks yang impersonal tanpa afeksi sifatnya.

Orang yang melakukan kegiatan pelacuran ini biasa disebut dengan PSK, yang menjual dirinya dengan melakukan hubungan seks untuk tujuan ekonomi. Menurut Soedjono D (1997), PSK adalah wanita yang menjual tubuhnya untuk memuaskan seksual laki-laki siapapun yang menginginkannya, dimana wanita tersebut menerima sejumlah uang atau barang. Adapun sebab-sebab terjadinya pelacuran ini ialah:

a. Rendahnya taraf kehidupan ekonomi rakyat

b. Banyaknya pengaruh barangbarang mewah sehingga mendorong orang untuk memilikinya.

c. Kehidupan rumah tangga yang tidak harmonis baik di bidang pergaulan, ekonomi, atau hubungan seks yang tidak memuaskan.

d. Meningkatnya film-film dan VCD porno, gambar-gambar cabul di masyarakat dimana penggemarnya sebagian besar adalah remaja sekolah. Sebab-sebab lainnya bisa dilihat dari faktor endogen dan eksogen. Faktor endogen seperti nafsu kelamin yang besar, sifat malas dan keinginan yang besar untuk hidup mewah. Faktor eksogennya yaitu faktor ekonomis, urbanisasi yang tidak teratur, 
keadaan perumahan yang tidak memenuhi syarat dan lain-lain. Sebab utama sebenarnya yaitu konflik mental, situasi hidup yang tidak menguntungkan pada masa anak-anak dan pola kepribadian yang kurang dewasa, ditambah dengan intelegensi yang rendah tarafnya.

PSK merupakan satu dari sekian banyak masalah yang sangat sulit untuk dibasmi selama kehidupan ini masih berjalan. Jika dipandang dari segi kaidah dan norma yang berlaku di masyarakat, masalah tersebut sangat bertentangan baik dengan undangundang positif, norma sosial apalagi dengan kaidah agama. Akan tetapi semua aturan tersebut seakan tidak dapat memproteksi masyarakat dari penyakit masyarakat tersebut.

2. Pekerja Seks Komersial dalam Perspektif Sosiologi

Secara sosiologis, perilaku menyimpang merupakan perilaku yang dianggap melanggar nilai dan norma yang berlaku di dalam masyarakat. Perilaku seperti ini terjadi karena seseorang mengabaikan norma atau tidak mematuhi patokan baku dalam masyarakat sehingga sering dikaitkan dengan istilah-istilah negatif. Hal ini merupakan penyakit masyarakat yang pada akhirnya dapat menghancurkan kepercayaan masyarakat. Beberapa teori penyimpangan sosial dalam pendekatan sosiologis yang terkait dengan PSK sebagai berikut:

a. Teori Anomie

Masalah PSK dapat dikaji menggunakan teori anomie oleh
Robert K. Merton, yang mana teorinya beranjak dari konsep anomie yang dikemukakan oleh Emile Durkheim, yang mengemukakan bahwa anomie sebagai suatu keadaan tanpa norma (deregulation) di dalam masyarakat yang kemudian menimbulkan perilaku deviasi. Teori anomie berasumsi bahwa penyimpangan adalah akibat dari adanya berbagai ketegangan dalam suatu struktur sosial sehingga ada individuindividu yang megalami tekanan dan akhirnya menjadi menyimpang. Termasuk di sini "pekerja seks komersial" yang merupakan bagian dari masyarakat yang tidak dapat menggunakan tujuan, cara, saranasarana yang sah dan kesempatan dalam mencapai tujuan. Tujuan yang dapat terlihat hanyalah semata-mata untuk memperoleh pekerjaan agar menghasilkan uang yang bisa digunakan untuk biaya hidup dan kebutuhan-kebutuhan yang lain. Itulah satu hal yang menjadi penyebab pelacuran marak terjadi dan menjadi pilihan di zaman yang serba susah ini.

b. Teori Asosiasi Diferensial Asosiasi diferensial adalah sebuah teori yang mempelajari tentang semua tingkah laku dalam hubungan interaksi dengan orang lain melalui proses komunikasi, dimana bagian penting dari mempelajari tingkah laku kriminal terjadi dalam kelompok yang intim. Menurut Sutherland, perilaku menyimpang yang dilakukan oleh seseorang sesungguhnya merupakan hasil dari proses belajar. Proses mempelajari suatu sikap dan tindakan terutama dari subkultur 
atau diantara teman-teman sebaya yang menyimpang.

Sutherland

mengemukakan juga menyimpang bersumber pada differential association (pergaulan yang berbeda). Para PSK akan "menekuni" kemudian "ahli" dalam aktivitasnya karena melalui sebuah pembelajaran berupa saluransaluran dengan kegiatannya berperilaku seks menyimpang. Hal ini berupa pelanggan-pelanggan yang bisa dikatakan media bagi PSK untuk belajar lebih mendalami peran pekerja seks itu.

c. Teori Kontrol

Kontrol sosial seringkali diartikan sebagai suatu pengawasan oleh masyarakat terhadap jalannya pemerintahan, khususnya pemerintah beserta aparatnya. Ini bertujuan untuk mencapai keserasian antara stabilitas dengan perubahan-perubahan dalam masyarakat serta untuk mencapai keadaan damai melalui keserasian antara kepastian dengan keadilan/kesebandingan.

Latar belakang dari teori kontrol adalah bahwa penyimpangan merupakan hasil dari kekosongan kontrol. Teori ini dibangun atas dasar pandangan bahwa setiap manusia cenderung untuk tidak patuh pada hukum atau memiliki dorongan untuk melakukan pelanggaran hukum.

d. Teori Labelling

Menurut

Becker, penyimpangan merupakan sebagai suatu konsekuensi dari penerapan aturan-aturan dan sanksi oleh orang lain kepada seorang pelanggar. Ini dimaksudkan bahwa menyimpang merupakan tindakan yang dilabelkan kepada seseorang atau pada siapa label secara khusus telah ditetapkan, sehingga tolok ukur penyimpangan itu ditetapkan bukan berdasarkan norma atau kualitas dari tindakan tersebut namun melalui reaksi masyarakatnya.

Analisis tentang pemberian label atau cap dipusatkan pada reaksi orang yang artinya ada orang-orang yang memberi definisi, julukan atau pemberi label pada individu-individu atau tindakantindakan yang menurut penilaian orang tersebut adalah negatif. Pemberian label yang menyimpang akan menghasilkan suatu peran sosial yang menyimpang pula. Artinya, dengan adanya cap yang dilekatkan pada diri seseorang yang diberi cap tersebut cenderung mengembangkan konsep diri yang menyimpang. Sebagai contoh seseorang yang berperilaku sebagai homoseksual demi uang, padahal tindakan itu dilakukannya dengan terpaksa. Namun, oleh karena masyarakat telah terlanjur memberinya cap sebagai reaksi terhadap tindakannya itu, maka akibatnya ia akan menjadi homoseksual yang sesungguhnya.

C. Hasil Penelitian

1. Latar Belakang Menjadi Seorang PSK
a. Proses Awal Menjadi Seorang PSK 
Secara umum, mereka terjun menjadi PSK berawal dari kehidupan mereka yang serba kekurangan. Namun, cara dan prosesnya berbeda-beda. Ada yang awalnya ikut teman, namun ada pula yang mencari tau sendiri informasi tentang PSK. Dari 4 PSK hanya $\mathrm{Ng}$ yang sebelumnya pernah mangkal di tempat lain. Hal ini sesuai dengan apa yang diungkapkannya:

“Dulu aku pertama kali di Parangkusumo mbak, tapi di sana pernah di gusur gitu ya aku langsung pindah sini, sempet jualan ikut orang tapi karena enggak laku saya malah kerja gini lagi di sini"

Dalam hal ini, masalah pelacuran dalam sebuah masyarakat secara scientific sangat tergantung dari kondisi masyarakat itu sendiri. Bila masyarakat tersebut masih teguh memegang norma-norma kesusilaan, kesopanan maupun agama namun sudah dirasuki gejala globalisasi yang mengarah ke modern yang melahirkan budaya konsumen pada kaum perempuan sehingga terpaksa melacur maka status dan peranan PSK tersebut secara teori anomie (goal dan means) akan mencari cara lain baik berupa tempat dan waktu untuk melakukan perannya yaitu menjajakkan diri, seperti pengakuan $\mathrm{Ng}$ diatas.

Berbeda dengan Dw, Dn maupun Gt yang belum pernah menjadi PSK di tempat lain. Alasan mereka mengambil pilihan di wilayah Prambanan terungkap dari pengakuan Dw yang telah 4 tahun mangkal di sana:
“Di sini enak, bebas, mau mangkal ya mangkal aja, tempatnya juga gak di tempat yang ramai banget tapi juga gak sepi"

Berbeda dengan pengakuan Ng yang mengatakan bahwa:

"Di sini bebas mbak, gak kayak di lokalisasi gitu malah gak enak soalnya malah tertekan mbak, terus juga hasilnya dibagi dua sama yang punya"

Bebas, tanpa tekanan, tanpa ikatan dan jauh dari kediaman keluarga inilah alasan mereka memilih lokasi di wilayah ini. Para PSK hanya manusia biasa yang tidak ingin kebebasannya diatur oleh aturan-aturan yang dapat membelenggu ataupun merugikan mereka.

b. Faktor-faktor yang Melatar belakangi Menjadi PSK

Di zaman globalisasi sekarang ini, salah satu cara agar kita dapat memperoleh uang guna memenuhi kebutuhan hidup seharihari salah satunya adalah dengan bekerja. Namun, untuk mendapatkan pekerjaan yang kita inginkan tidak semudah membalikkan telapak tangan. Berbagai macam persyaratan yang diajukan serta persaingan yang ketat semakin banyak dan jika kita tidak memiliki persyaratan tersebut dikatakan gagal dalam mendapatkan pekerjaan tersebut. Oleh karena itu, berbagai jenis pekerjaanpun akan dilakukan seseorang guna mendapatkan uang. Seperti halnya yang dilakukan oleh para PSK. Dari hasil wawancara peneliti terhadap 4 wanita yang terlibat prostitusi, ada 
beberapa faktor yang dapat diungkapkan yang mejadi alasan mereka menjadi PSK. Faktor tersebut antara lain:

1) Faktor Ekonomi

Faktor dominan yang membuat mereka bekerja menjajakkan diri sebagai wanita PSK adalah karena faktor ekonomi. Faktor ekonomi secara operasionalnya adalah sulit memenuhi kebutuhan mereka sehari-hari dikarenakan tidak adanya pekerjaan yang menghasilkan uang yang cukup untuk dapat memenuhi kebutuhan sehari-hari. Seperti yang dikatakan $\mathrm{Ng}$, Salah seorang dari mereka yang mana $\mathrm{Ng}$ terpaksa bekerja menjadi seorang PSK karena tidak adanya pekerjaan yang dapat memenuhi kebutuhan keluarganya sehari-hari. Hal ini sesuai dengan pengakuan Ng yang mengatakan:

"Ya karena masalah ekonomi mbak, buat menuhin kebutuhan hidup sehari-hari"

Hal senada juga diungkapkan oleh Dw dengan singkatnya:

"Cari duit buat beli kebutuhan tiap hari"

Mencari uang untuk memenuhi kebutuhan sehari-hari adalah alasan mereka bekerja sebagai PSK. Hal ini sesuai apa yang diungkapkan Soekanto yang mengatakan bahwa sebab terjadnya pelacuran bisa dilihat dari faktor eksogennya seperti faktor ekonomi. Faktor atau tekanan ekonomi yang membuat mereka menjerumuskan diri dalam pelacuran merupakan akibat lanjut dari adanya kemiskinan struktural yang menjadi kenyataan telanjang di depan mata. Ini merupakan imbas dari struktur kebijakan yang tidak memihak kepada mereka.

2) Sulitnya Mencari Pekerjaan Setiap manusia diberi kebebasan untuk memilih jenis pekerjaannya sesuai dengan kemampuan dan kesenangannya. Tetapi hidup di dunia ini bukan tanpa batasan. Kalaupun bukan kita sendiri yang membatasi, kita akan mendapatkan batasan-batasan tertentu seperti batasan atas dasar norma sosial dan norma agama. Sehingga dari batasan tersebut ada pekerjaan yang nampaknya masih dalam batas boleh dilakukan dan ada juga yang tidak boleh.

Ketika sudah bicara mengenai batasan normatif, maka pandangan mengenai pekerjaan akan beragam. Namun, pada kenyataannya, walau dengan batasan-batasan yang ada masih banyak juga orang yang memilih bekerja sebagai PSK. Sebuah pekerjaan yang kontroversial dan sarat akan masalah. Hal ini seperti yang diungkapkan oleh $\mathrm{Ng}$ :

"Ya karena enggak ada kerjaan mbak, mau gimana lagi, sekarang kan cari kerjaan itu susah mbak"

Hal senada juga diungkapkan oleh Gt:

"Gak ada kerjaan lain mbak, sulit nyari kerja sekarang mbak apalagi cuma lulusan SMP kayak saya ini" 
Sebenarnya masalah PSK adalah masalah yang tidak sepenuhnya berasal dari kesalahan PSK itu sendiri, namun kadang secara sosiologis problema tersebut muncul dikarenakan salah satu lembaga masyarakat yaitu di bidang ekonomi yang tidak berfungsi dengan baik. Ketidakberfungsian tersebutlah yang akan membuat kepincangan di dalam fungsi lembaga yang akan menjalar ke bidang-bidang lainnya. Ditambah pula ketidakmerataan pembangunan yang ada di masyarakat kadang membuat sebagian orang tidak memiliki peluang untuk memperbaiki hidup ke taraf yang lebih baik.

3) Rendahnya Pendidikan

Pendidikan merupakan suatu transformasi warisan budaya seperti pengetahuan, nilai-nilai dan keterampilan-keterampilan yang salah satunya disalurkan melalui lembaga-lembaga pendidikan. Peranan pendidikan dalam drama kehidupan dan kemajuan umat manusia semakin penting. Ini dikarenakan semakin berkembangnya peradaban manusia yang secara otomatis berkembang pula permasalahan hidup yang dihadapi manusia.

Tingkat pendidikan yang tinggi yang ditempuh seseorang akan membawanya pada keberuntungan hidup tersendri dibandingkan dengan seseorang yang hanya menempuh pendidikan rendah dan ditambah pula dengan tidak mempunyai keterampilan khusus. Ini sama halnya yang terjadi dengan para PSK. Mereka hanya berpendidikan rendah yang mengakibatkan mereka sulit untuk mendapatkan pekerjaan. Sebagaimana yang diungkapkan $\mathrm{Ng}$ : mbak"

"Saya cuma lulusan SMP Hal senada juga diungkapkan Gt yang juga lulusan SMP:

"Wah pendidikan saya rendah kok mbak, cuma SMP gak bisa sekolah tinggi-tinggi gak punya uang"

Tingkat pendidikan memang menjadi faktor penting dalam mencari pekerjaan. Dengan tingkat pendidikan yang tinggi orang bisa sesukanya memilih pekerjaan dan jabatan yang diiginkannya. Namun sebaliknya, orang yang tingkat pendidikannya rendah seolah-olah tidak lagi memiliki kesempatan atau peluang untuk bisa mendapatkan pekerjaan yang diinginkannya.

Selain berpendidikan rendah, faktor tidak adanya keahlian khusus yang dimiliki para PSK juga membuat mereka tidak bisa mendapatkan pekerjaan yang semestinya. Dengan bermodal tubuh saja mereka mampu untuk mendapatkan uang yang mereka inginkan tanpa harus menunjukkan ijazah apa yang mereka miliki.

4) Faktor Penghasilan Menjadi PSK yang Lebih Mencukupi Untuk Memenuhi Kebutuhan Pilihan bekerja sebagai PSK tidak muncul begitu saja tetapi atas dasar berbagai macam pertimbangan, salah satunya karena hasil dari menjajakkan diri yang lebih mencukupi kebutuhan. Hal ini terbukti dari rata-rata informan 
yang sebelumnya pernah bekerja di bidang lain. Seperti pengakuan $\mathrm{Ng}$ yang mengatakan:

".......sempet jualan ikut orang itu berdagang tapi karena enggak laku, malah rugi ya saya malah kerja gini lagi "

Pendapatan yang mereka peroleh perhari memang tidak banyak antara 100.000 s.d 300.000, namun jika dihitung perbulannya mereka bisa menghasilkan 2 jutaan lebih. Hal ini diungkapkan oleh Dw yang mengatakan:

"gak mesti, paling dikit ya 100.000, paling banyak ya kadang 300.000"

Dilihat dari segi moral dan naluri, seorang PSK juga manusia yang butuh makan dan sesuatu untuk bertahan hidup. Maka tidak ada salahnya jika mereka bekerja menggunakan tubuh mereka sebagai modal, karena memang hanya itu yang mereka punya. Namun, jual diri merupakan salah satu titik keputusasaan dimana sudah tidak ada lagi cara untuk memenuhi kebutuhan hidupnya, tetapi hal itu juga berubah menjadi ketergantungan dimana dengan mudahnya mereka mendapatkan rupiah demi rupiah hanya dengan memuaskan nafsu para hidung belang dan mereka sendiri juga merasakan kepuasan.

5) Faktor Keluarga

Selain faktor-faktor di atas, faktor yang membuat PSK terjun ke dunia hitam ini salah satunya adalah karena masalah di dalam keluarga. Problema yang dihadapi di dalam keluarga menuntut mereka bekerja sebagai PSK. Seperti pengakuan Dn yang mengatakan:

"Saya kerja gini terpaksa mbak soalnya suami saya udah pergi ninggalin saya dan anak-anak, perginya tu gak pamit mbak, gak tau kemana, jadi ya saya mau gak mau cari duit mbak buat anak saya, buat beli susu anak saya yang masih bayi"

Berbeda dengan pengakuan Dw, Ng dan Gt yang memiliki suami yang juga bekerja. Namun, pekerjaan suaminya tidak menghasilkan uang yang cukup untuk memenuhi kebutuhan seharihari, seperti pengakuan Gt saat di wawancara:

"Suami saya ya di rumah cuma kerja di sawah mbak, tani gitu, jadi yo gak ada penghasilan apa-apa"

Berdasarkan perspektif labelling, masalah kemiskinan di dalam keluarga ini bersifat relatif tergantung bagaimana interpretasi dari masing-masing orang. Walaupun dengan mengunakan standar tertentu sseorang sudah dinyatakan sudah tidak miskin lagi, akan tetapi ia tetap merasa berada dalam kondisi miskin apabila yang bersangkutan menginterpretasikannya masih berada dalam kondisi seperti itu.

2. Persepsi Masyarakat Terkait Fenomena PSK
a. Pandangan Masyarakat Mengenai PSK
Kultur Indonesia merupakan kultur yang heterogen, setiap aspek kehidupan terpengaruh kepada hal 
yang berbau globalisasi. Berangkat dari kata globalisasi, pola hidup maupun kebutuhan lahiriah menjadi berubah. Hal ini juga menjadi sebab seorang wanita menjadi PSK. Masalah PSK yang ada di masyarakat semakin hari semakin bertambah. Banyak faktor mengapa seseorang menjalani pekerjaan sebagai PSK. Apapun faktor dan penyebabnya, masyarakat tetap mempunyai persepsi ataupun pandangan yang berbeda-beda tentang pekerjaan tersebut. Persepsi ataupun pandangan tersebut merupakan pengalaman tentang objek, peristiwa atau hal-hal yang diperoleh dengan menyimpulkan informasi dan menafsirkannya melalui penglihatan, pendengaran maupun perasaannya.

Dari kondisi latar belakang sosial masyarakat yang berbedabeda, di dapat gambaran mengenai pandangan mereka mengenai masalah PSK yang mangkal di wilayah mereka. Dari keterangan beberapa warga sekitar di peroleh informasi bahwa keberadaan PSKPSK di wilayah mereka sebetulnya bukan tidak diketahui oleh warga. Hampir semua warga masyarakat mengetahui mengenai PSK-PSK yang menggunakan wilayah mereka sebagai tempat mangkal. Hal ini sesuai yang diungkapkan oleh Bapak Rm:

"Ya tau, semua orang di daerah sini pada tau mbak kalau di sana tu ada perempuan-perempuan begitu, tapi saya juga tidak pernah kenal langsung orang-orangnya"
Hal ini juga diperkuat oleh salah satu informan yaitu Ibu Ms yang mengatakan bahwa:

"Iya taulah mbak"

Wilayah yang telah lama digunakan sebagai tempat mangkal PSK pasti membawa pandangan negatif terhadap masyarakat, meskipun pandangan tersebut hanya dijadikan sebagai unek-unek saja tanpa ada tindakan yang nyata. Hasil temuan penelitian di lapangan terdapat pandangan negatif dari masyarakat tentang adanya PSK seperti yang diungkapkan oleh Ibu Ms:

"Ya tidak setuju mbak desa kami dipake tempat seperti itu, lah wong tetangga-tetangga di sini juga pada ngomongin mereka, gak bener ini mbak cewe-cewe kayak gitu ada di sini"

Hal ini juga disampaikan oleh Bapak Sy:

"Ya sebenarnya tidak setujulah tapi juga gimana ya mbak itu bukan orang sini juga gak tau".

Pandangan negatif yang tercipta dari masyarakat inilah yang kemudian menciptakan suatu label atau pemberian cap terhadap para PSK tersebut. Pemberian cap kepada seseorang yang menyimpang diharapkan mampu mejadi sanksi sosial yang dapat membuat pelaku penyimpangan tidak lagi melakukan tindakan di luar norma masyarakat.

b. Dampak Adanya PSK di
Masyarakat
Adanya PSK yang mangkal tidak membawa dampak yang sangat serius di dalam masyarakat. Ini dikarenakan para PSK tersebut 
bukanlah orang-orang dari warga sekitar. Hal ini diungkapkan oleh Bapak Rm yang mengatakan:

"Gak ada dampak apa-apa si mbak soalnya bukan warga sini, yang suka bawa juga bukan orangorang sini"

Walaupun tidak membawa dampak yang serius, tetapi masyarakat sedikit terganggu kenyamanannya karena dengan adanya PSK yang mangkal di wilayah masyarakat maka wilayah mereka mendapatkan citra negatif dari masyarakat luar. Hal ini diungkapkan oleh Ibu Ms yang mengatakan:

"Ya tidak ada dampak apaapa mbak, cuma kan nama desa kami jadi jelek mbak, nanti orang kira kami dukung adanya mereka, kan gak bener ini mbak"

Selain Dampak dari PSK yang menyebabkan citra desa yang menjadi taruhannya namun juga mengganggu lingkungan seperti mengganggu ketertiban dan kenyamanan lingkungan warga sekitar. Hal inilah yang setiap harinya membuat resah warga masyarakat yang bertempat tinggal di wilayah tersebut.

\section{c. Upaya Penanggulangan PSK Sudah menjadi rahasia} umum bahwa wilayah mereka terdapat para PSK mangkal. Namun menurut mereka, tidak ada upaya yang bisa dilakukan. Hal ini terungkap dari ibu Ms:

"Ya gak bisa berbuat apa-apa
mbak, paling cuma tetangga- tetangga pada ngomongin aja, orang mereka bukan warga sini"

Di dalam masyarakat yang makin kompleks dan modern dimana usaha penegakan kaidah sosial tidak bisa lagi dilakukan hanya dengan mengandalkan kesadaran warga masyarakat atau peran dalam masyarakat tidak lagi dapat berfungsi sebagaimana mestinya maka usaha kaidah di dalam masyarakat harus dilakukan oleh kehadiran aparat petugas kontrol sosial seperti pihak kepolisian. Adanya usaha aparat kepolisian ini sebagaimana yang diungkapkan oleh Bapak Rm yang mengatakan:

"Kalau garukan (razia) itu dulu di sana mbak, di sini gak pernah ada mbak, lagian kalau garukan itu malam mbak di sana"

Hal senada juga diperkuat oleh pengakuan salah satu PSK yaitu $\mathrm{Ng}$, yang mengatakan bahwa:

"Kalau di sini gak pernah ada mbak, pernah ada tuh di sana deket pasar kambing itu "

Dari pernyataan $\mathrm{Ng}$ tersebut, jelas bahwa para PSK telah mengetahui bahwa titik yang mereka jadikan tempat mangkal tidak akan terkena razia polisi. Selain itu juga, upaya masyarakatpun tidak ada untuk mengusir mereka sehingga mereka juga berkeyakinan bahwa apa yang mereka lakukan saat ini tidak membuat kekacauan di wilayah tersebut sehingga mereka yakin kalau masyarakatpun tidak akan menggusur tempat mangkal mereka. 
Aparat kepolisian memang telah berusaha melakukan tugasnya namun apa yang dilakukan oleh aparat petugas kontrol sosial tersebut belum sepenuhnya membuahkan hasil yang maksimal. Hal ini dikarenakan belum menyeluruhnya tempat-tempat mangkal yang dilakukan razia oleh pihak kepolisian. Jika masyarakat dan aparat penegak kontrol sosial seperti kepolisian belum dapat melakukan fungsi kontrolnya secara maksimal dan menyeluruh, hal ini mengakibatkan permasalahan sosial yang ada di masyarakat belum dapat terselesaikan dengan tuntas.

\section{Pokok-pokok Temuan Hasil Penelitian}

Dari penelitian yang telah peneliti lakukan, pneliti menemukan hal-hal penting yang ditemukan peneliti selama melakukan penelitian. Adapun halhal tersebut adalah sebagai berikut:
a. Adanya PSK telah berlangsung lama sekitar bertahun-tahun yang lalu

b. PSK tersebut dapat dikategorikan PSK jalanan yaitu PSK kelas rendah.

c. Para wanita yang bekerja menjadi PSK mengaku melakukannya karena motif ekonomi untuk memenuhi kebutuhan sehari-hari. Selain faktor ekonomi juga ada faktor lain yaitu sulitnya mencari pekerjaan, rendahnya tingkat pendidikan, faktor penghasilan menjadi PSK yang lebih mencukupi untuk memenuhi kebutuhan hidup serta faktor keluarga.

d. PSK-PSK yang mangkal di wilayah Kebondalem Kidul ini dapat ditemui pada harihari pasaran seperti legi dan pon.

e. Diantara PSK yang diwawancarai, belum ada yang ingin beralih mencari pekerjaan lain karena sulitnya mendapat pekerjaan yang penghasilannya lebih mencukup kebutuhan hidup PSK.

f. Para PSK dan pengguna jasa bukan dari warga sekitar.

g. Pengguna jasa berasal dari kalangan masyarakat menengah. Hal ini juga dipengaruhi oleh faktor PSK yang termasuk PSK liar kelas rendah.

h. Masyarakat sekitar tidak mampu berbuat banyak dalam menangani kasus PSK yang ada di wilayah mereka dikarenakan para PSK dan pengguna jasa bukan dari warga sekitar.

i. Tindakan polisi merazia PSK belum maksimal ke semua tempat yang dijadikan tempat mangkal PSK khususnya yang dijadikan lokasi penelitian.

\section{Kesimpulan}

Masalah sosial yaitu pekerja seks komersial (PSK) memang sudah lama adanya yaitu sudah berlangsung bertahun-tahun yang lalu. Hingga saat ini masalah tersebut masih ada dan semakin marak saja. PSK menjadi masalah 
sosial karena tindakan yang dilakukannya merupakan tindakan menyimpang yang tidak hanya merugikan diri sendiri namun juga merugikan orang lain, dalam hal ini lingkungan sekitar. Bekerja menjadi seorang PSK, baik atau tidaknya dapat dilihat dari berbagai macam sudut pandang. Dilihat dari sudut agama, adat-istiadat dan masyarakat secara umum maka dapat dikatakan hal tersebut tidak baik karena dianggap bagian dari perbuatan yang melanggar normanorma masyarakat secara keseluruhan. Namun, jika melihat dari pekerja itu sendiri akan dapat dikatakan bahwa menurut mereka itu adalah jalan yang terbaik untuk menyelamatkan hidup mereka dan keluarga.

Setiap PSK memiliki faktor yang menyebabkan mereka melakukan pekerjaan tersebut, diantaranya adalah faktor ekonomi dimana pada awalnya mereka memang berasal dari keluarga yang kurang mampu. Selain faktor ekonomi juga ada faktor rendahnya tingkat pendidikan, penghasilan yang lebih dapat memenuhi kebutuhan sehari-hari serta problem yang ada di keluarga. Para PSK yang ada di wilayah ini adalah termasuk PSK liar yang mana mereka berinteraksi langsung dengan para lelaki hidung belang tanpa menggunakan jasa perantara atau yang biasa disebut germo. Hal ini merupakan salah satu alasan para PSK memilih wilayah ini sebagai tempat mangkal. Selain itu lokasi yang strategis juga menjadi alasan mereka. Strategis dalam hal ini adalah tidak dekat dengan rumah atau keluarga dan juga tidak terlalu jauh untuk dijangkau pulang-pergi menggunakan transportasi angkutan umum seperti bis.

Pandangan negatif muncul dari masyarakat setempat karena dengan adanya PSK-PSK tersebut membuat citra negatif yang ditujukan kepada wilayah mereka. Namun, pada kenyataannya masyarakat tidak melakukan upayaupaya apapun untuk mengusir para PSK karena mereka menganggap PSK dan pengguna jasa bukanlah dari warga mereka sehingga masyarakat lebih memilih acuh tak acuh dan hanya mempergunjingkannya di belakang tanpa melakukan tindakan yang nyata.

Kontrol sosial dari masyarakat yang tidak berfungsi dengan semestinya membuat tempat mangkal PSK belum dapat dimusnahkan dari sekian tahun yang lalu. Begitu pula dengan apa yang dilakukan oleh aparat penegak kontrol sosial seperti pihak kepolisian. Pihak kepolisian melakukan razia tidak secara menyeluruh dan maksimal. Ini dibuktikan dengan tidak pernah ada razia ditempat mangkal para PSK yang dijadikan objek penelitian. Sehingga masalah ini terus berlangsung dari tahun ke tahun. 
| Siti Munawaroh

\section{Daftar Pustaka}

J. Dwi Narwoko-Bagong Suyanto (ed.), Sosiologi Teks Pengantar dan Terapan, Jakarta: Kencana Prenada Media Group, 2004, hlm 90.

Elya Rita W, dkk. 2008. Laporan KKL III: Fenomena Prostitusi di Cipanas dan Carita. Yogyakarta: UNY

Soetomo. 1995. Masalah Sosial dan Pembangunan. Jakarta: PT Dunia Pustaka Jaya
Soerjono Soekanto. 2002. Sosiologi Suatu Pengantar. Jakarta: Rajawali Pers

Sumitro, dkk, Pengantar Ilmu Pendidikan, Yogyakarta: UNY Press, 2006, hlm.17.

Sofyan S. Willis. 2005. Remaja dan Masalahnya. Bandung: Alfabeta 